\title{
Vincent Hugonnot
}

\section{Bryophytes of the Gorges de l'Ardèche (Ardèche and Gard, southern France)}

\begin{abstract}
Hugonnot, V.: Bryophytes of the Gorges de l'Ardèche (Ardèche and Gard, southern France). Fl. Medit. 24: 163-196. 2014. — ISSN: 1120-4052 printed, 2240-4538 online.

The bryoflora of the Gorges de 1'Ardèche has been bryoflostically investigated. The previously published records, corresponding to 27 taxa, have been taken into account. Today, 216 bryophyte taxa are confidently recorded in the Gorges de l'Ardèche site. It is considered as a local hot-spot of bryological diversity in a south-eastern France context. Several genera are of special ecological interest: Didymodon, Orthotrichum, Bryum, Fissidens and Riccia. More than 20 remarkable species are additionally recorded: Acaulon triquetrum, Aleniella besseri, Barbula bolleana, Bryum canariense, Cheilothela chloropus, Cinclidotus danubicus, Didymodon nicholsonii, Ephemerum recurvifolium, Fissidens fontanus, Grimmia tergestina, Homalia lusitanica, Homalothecium aureum, Mannia californica, Marchantia paleacea, Orthotrichum philibertii, Orthotrichum sprucei, R. trabutiana, Radula lindenbergiana, Riccia cavernosa, Scorpiurium sendtneri, Timmiella anomala and Tortella inflexa. A significant number of species is largely dependant upon the natural functioning of the Ardèche river, with an intense alluvial activity and remodelling of river banks. Most forest stands are young ones, originating from forest recolonization of ancient pastoral areas. The conservation of the bryophyte communities is very simple and shall be based upon the principle of minimum intervention. An improvement of the waste water disposal systems of many campsites is needed.
\end{abstract}

Key words: floristics, alluvial functioning, Quercus ilex woodlands.

\section{Introduction}

The Gorges de l'Ardèche are located in south-eastern France and are among the most important tourists destination of Rhône-Alpes region. It is a renowned place of interest among European kayakers, climbers and naturists! The very deep and parallel Gorges are outstanding natural features of high aesthetic value which bring tourists coming in hordes (more than 50000 a year). The substantial network of trails is walked by hikers and the river is well known over Europe among canoeing and kayaking enthusiasts and also provides outstanding opportunities for swimming. The unique natural heritage is to be conserved and the Réserve Naturelle Nationale des Gorges de l'Ardèche was created in 1980 and covers an area of 1575 hectares. 
The recent publication of the "mousses et hépatiques de Païolive" (Hugonnot 2010) brought to light the extraordinary natural heritage of this site situated less than $50 \mathrm{~km}$ west from the Gorges de l'Ardèche. Yet the bryoflora of the south-eastern part of the Massif Central remains still very poorly investigated and a lot remains to be done before we arrive at a definite picture of its genuine richness. In this context of exceptional bryofloristic interest, we repeatedly surveyed the Gorges de l'Ardèche since more than 10 years.

The aim of this study is principally to provide a floristic checklist of the mosses and liverworts of the Gorges de l'Ardèche, describe the ecology and frequency of all recorded taxa, and comment up on the most remarkable records. Lessons for improving the conservation action plan will be taken.

\section{Background}

\section{History of bryological exploration}

Comprehensive investigations of the bryophytes of Ardèche are totally lacking. The two most substantial publications are that of Debat (1886) and Meyran (1914) who enumerated the bryoflora of the Rhône basin. The Gorges de l'Ardèche are only peripherically mentioned in these works. Dismier $(1921,1922,1928)$ and Philibert $(1880,1881,1884 \mathrm{a}$, $1894 \mathrm{~b}$ ) present additional information in shorter papers who make only incidentally mention to the study area. Sapaly (2000) bring together the body of information in a department synthesis. More recently, Wattez \& De Foucault (2002) provided floristic lists from sites in the Gorges de l'Ardèche. The bryoflora of the site is in spite of the aforementioned works still very badly known. Only Dismier (1928), Pierrot \& al. (1991), Petit (2002) and Wattez \& De Foucault (2002) published floristic data concerning the Gorges de l'Ardèche.

\section{Geology and geomorphology}

The Gorges de l'Ardèche are located in the south-eastern part of Ardèche department between Vallon-Pont-d'Arc and Saint-Marcel d'Ardèche (Fig.1). The meandering 30 $\mathrm{km}$ long canyon results from a prolonged phase of incision of limestone in Urgonian facies (Pascal \& al. 1989; Astrade \& al. 2011). Today the main morphogenetic forces driving the Gorges functioning are alluvial processes (Bravard 1993). The general structure of the Gorges is deeply marked by the impressive semi-circular amphitheatres called cirques. The river winds its way below the cliffs and not less than 20 meanders alternate with rapids where turbulent water zones form because of the accumulation of rock debris in the channel bottom or because the river strongly narrows (Julien 2006).

The Ardèche river is of torrential regime and receives several tributaries, among which the Chassezac and the Beaume are the most important. Cevénnes influenced rainfall patterns combine with steep slopes to cause severe flooding events (Bravard 2008). If the average flow is relatively modest $\left(55 \mathrm{~m}^{3} / \mathrm{s}\right)$, flooding events are of severe nature mostly at the end of the summer or at the beginning of the autumn with 2000 à $3000 \mathrm{~m}^{3} / \mathrm{s}$. The water level of Ardèche was much higher in the past, at the XIX ${ }^{\text {th }}$ century (Astrade \& al. 2011) following the deposition of a very important quantity of alluvium during the Little Ice Age. 


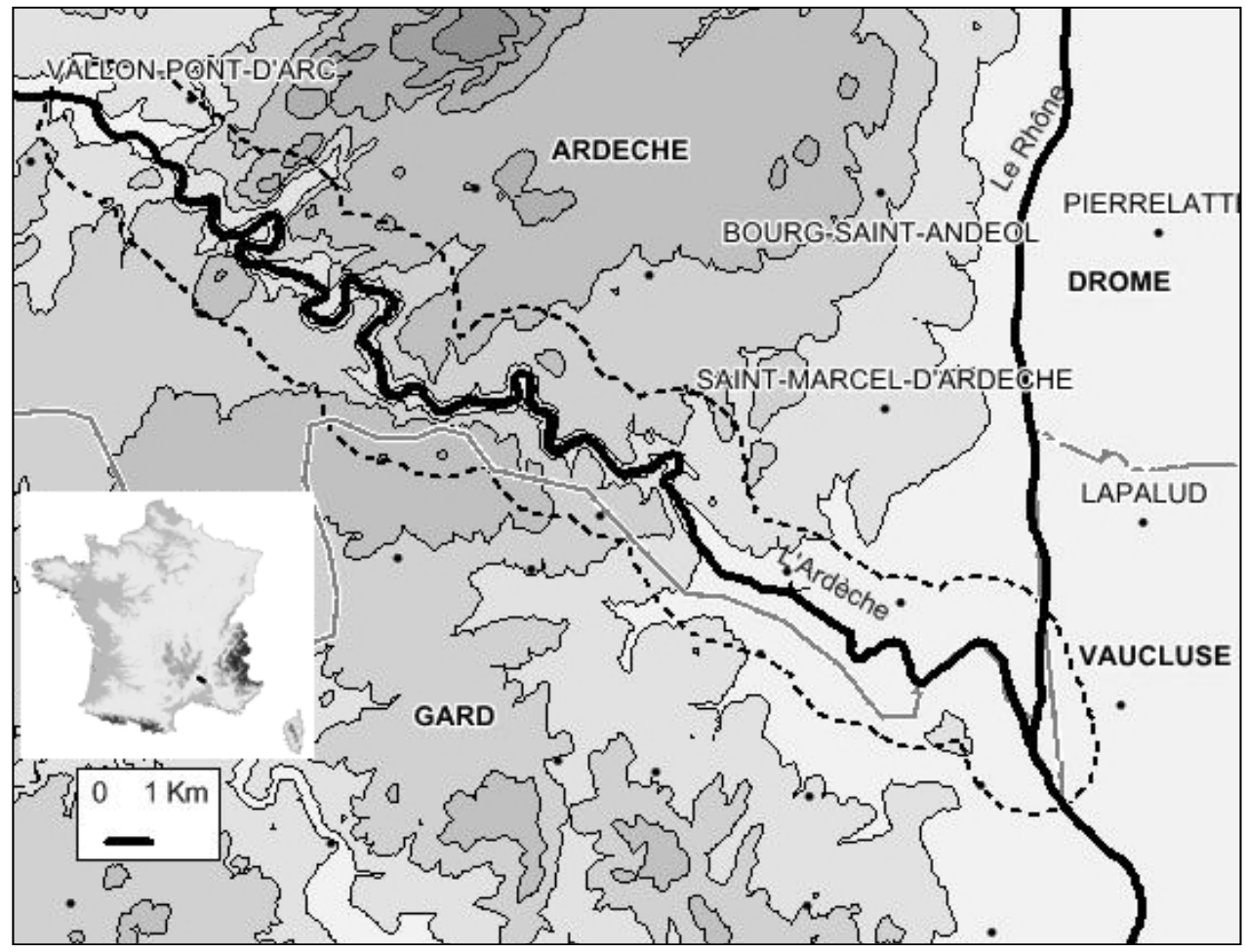

Fig. 1. Gorges de l'Ardèche site.

The devastating flows of Ardèche during last centuries (leading to an elevation of the level rising to $20 \mathrm{~m}$, De Mardigny 1860) gradually evacuated these alluvial loads. Such exceptional floods are linked to particular historical and climatic conditions and are not likely to recur today but current flood events lead nonetheless to rise of level from 8 to $10 \mathrm{~m}$. The Ardèche river is entrenched in the eroded limestone repositories. At the foot of the cliffs deep water area are called "mouilles" in front of which convex pebble banks are formed (Bravard 2008). During flooding events, coarse sediments which accumulate in the "mouilles" are carried again and deposited downstream. Pebble banks may reach several $\mathrm{m}$ high. Fine sediments originating from metamorphic or granitic Cévennes are carried downstream by the rivers settle from suspension (Jaillet \& al. 2008).

\section{Climate}

The climate of Gorges de l'Ardèche contributes substantially to its bryofloristic interest. It is supramediterranean with high level of sunshine and moderate total annual rainfall (less than $1000 \mathrm{~mm} /$ year). The summers are warm so that the vegetation endure prolonged period of drought (from June to September) which is in striking contrast with the many rainy days of Autumn and Summer. Winter is relatively warm and dry. The new implementation of weather stations in the deep Gorges demonstrated that several sites never endure negative temperatures (Peyronel pers. comm.). 


\section{Flora and vegetation}

A partial approach on vegetation description is given in Mandin \& Descoings (2008) and Choisnet \& Le Henaff (pers. comm.). Some details towards a phytosociological classification of vegetation are provided in the following.

Long-lived grasslands communities growing on calcareous pavements with Sedum ochroleucum and S. sediforme (Sedion micrantho-sediformis Rivas-Martínez, SánchezGómez \& Alcaraz in Sánchez-Gómez \& Alcaraz 1993) are rather extensive. In contrast, rarer mesomediterrean short-lived groupings with Vulpia ciliata, Trigonella monspeliaca, Bombycilaena erecta, mostly oligotrophic are part of the Trachynion distachyae RivasMartínez ex Rivas-Martínez, Fern.-Gonz. \& Loidi 1999. Many associations are probably concerned but they are not dealt with here. Poorer Aphyllantes monspeliensis groupings on marly limestone outcrops are refered to Helianthemo italici-Aphyllanthion monspeliensis Díez Garretas, Fernández González \& Asensi 1998. Under the influence of low grazing level, tall herbs Brachypodium retusum, Bromus erectus and Brachypodium phoenicoides extensive grasslands (Phlomido lychnitidis-Brachypodion retusi G. Mateo 1983) come to dominate. Open garrigues (Rosmarinion officinalis Br.-Bl. ex Molinier 1934) are dominated by widely spaced Thymus vulgaris leaving a considerable amount of bare or stony ground between the shrubs and exhibiting a great diversity of Mediterranean plants and other organisms. Mesomediterraean Centranthus lecoqii and Galeopsis angustifolium subsp. angustifolium (Pimpinello tragium-Gouffeion arenarioidis Br.-Bl. in Br.-B1., Roussine \& Nègre 1952) community is well developed on steep unstable calcareous scree slopes. Impressive calcareous cliffs are home of a definite light-requiring community with Hormatophylla macrocarpa. Calcareous pavements are made of a complex and repetitive mosaic of grikes and clints. This highly patterned structure allows a rich assemblage of specialized communities to develop. The mesomediterranean hottest and driest calcareous rocks are home of the specialized Asplenium petrarchae (Guérin) DC. community (Asplenion glandulosi Br.-B1. \& Meier in Meier \& Br.-B1. 1934). More protected from direct insolation rocks are colonized by the sciaphilic Asplenium trichomanes subsp. pachyrachis and Polypodium cambricum (Polypodion serrati Br.-Bl. in Br.-Bl., Roussine $\&$ Nègre 1952). Aside from stoneworts communities which were not the subject of any particular survey, the wet habitats are diversified along Ardèche course or tributary rivulets:

- Submerged perennial vegetation dominated by clumps of Ranunculus fluitans (Batrachion fluitantis Neuhäusl 1959);

- Short-lived amphibious Lythrum thymifolia and Juncus bufonius community (Radiolion linoidis Pietsch 1971);

- Eleocharis palustris mesotrophic swamp of margin of riverbed often spring-fed (Oenanthion aquaticae Hejný ex Neuhäusl 1959);

- Mediterranean nutrient-rich wet grasslands with Cyperus longus and Paspalum distichum (Paspalo distichi-Agrostion semiverticillatae Br.-Bl. in Br.-Bl., Roussine \& Nègre 1952); - several communities invade alluvial banks with Chenopodium mite, Xanthium italicum, Ptychotis saxifraga and Glaucium flavum of Chenopodion rubri (Tüxen ex Poli \& J. Tüxen 1960) Kopecký 1969. 
Mediterranean Saponaria officinalis and Scrophularia canina vegetation (Glaucion flavi Br.-Bl. ex Tchou 1948) on instable sand and gravel mixed calcareous-siliceous substrate is best expressed along Ardèche river.

Bryophyte associations of tufa are not very abundant along Ardèche course but are rather diversified. The community characterized by an excellent and durable water supply dominated by Palustriella commutata (Pellion endiviifoliae Bardat in Bardat et al. 2004 prov.) is very scarce in the site. The most widespread tufa association is the Eucladietum verticillati Allorge 1921, with Eucladium verticillatum in trickling water zones at the base of calcareous cliffs. It is of almost ubiquitous occurrence but on many occasion limited to small cushion of the character moss. Travertine (indurated and dry tufa) communities are dominated by mosses and liverworts more typical of forest rocks. The sciaphilic vegetation of calcareous cliffs with high humidity is referred to Adiantion capilli-veneris Br.-Bl. ex Horvatić 1939.

Mesomediterranean evergreen oak woods (Quercion ilicis Br.-Bl. ex Molinier 1934) are far more abundant than supramediterranean deciduous ones (Quercion pubescenti-sessiliflorae Br.-B1. 1932). Quercus ilex is the most widespread and typically dominant tree on most of the harsher soils slopes. The forests of the site have been almost systematically cut so that practically no ancient woodland is locally preserved. There are many degradation stages (garrigues grasslands), that are mainly maintained by grazing. Alluvial forests are settled along the Ardèche permanent river. They are of more exceptional occurrence along smaller water courses. They strongly depend on regular flooding. Four softwood main communities could be distinguished:

Salix purpurea and Saponaria officinalis stands (Salicion triandrae Müller \& Görs 1958) on instable alluvial banks;

Regularly flooded low-lying stands of Salix alba (Salicion albae Soó 1930);

Alnus glutinosa and Fraxinus angustifolia community on low-lying gravel beds and Fraxinus angustifolia and Populus alba ones on less regularly flooded banks but with high water table (Populion albae Br.-Bl. ex Tchou 1948);

Populus nigra stands of high terrasses of sand (Rubo caesii-Populion nigrae Passarge 1985).

\section{Methods}

Bryophytes were collected by the author in the Gorges de l'Ardèche since 1999 and more regularly over 2007 to 2012 . The use of a boat proved very useful to survey the main river channel along the entire water course from western Vallon-Pont-d'Arc to the confluence of Ardèche and Rhône. The study area (Fig. 1) is defined as containing the water course of Ardèche from Vallon-Pont-d'Arc to the confluence with the Rhône and encompassing both riversides to a distance of $1500 \mathrm{~m}$.

No attempts were made to verify published records if those have been observed in the field by the author. The records appearing in print or no of N. Bianchin, J. Celle, G. Dismier, B. De Foucault, F. Kessler, J.P. Mandin, D. Petit, J.C. Vadam and J.R. Wattez have 
been incorporated in the study. The published records are mentioned in the systematic list. In all 27 taxa were previously mentioned from that area. Gyroweisia tenuis (Hedw.) Schimp. and Encalypta rhaptocarpa Schwägr. (Wattez \& De Foucault 2002) are excluded from the list as they correspond to errors.

A total of approximately 2000 personal collections were examined. All the corresponding material is deposited in the herbarium of the Conservatoire Botanique National du Massif Central. The material stored in PC was also examined.

Taxa, liverworts and mosses are given in alphabetic order. Nomenclature of species according to Ros \& al. (2007) for liverworts, Ros \& al. (2013) for mosses and Kerguélen (1993) for vascular plants.

Comments relating to identification or taxonomy are given first. Ecological description is given in a frequency of occurrence order. Detailed habitat description is provided for all personal collections. The number of records is given. Liverworts and mosses found during the field works are listed below in a strict alphabetical order.

\section{Results}

216 taxa of bryophytes (206 species plus 9 var. and one subsp.) are reliably recorded from the Gorges de l'Ardèche, among which 35 liverworts and 181 mosses.

Red listed taxa are listed with their respective status in the Tab. 1. It should be noted that Ephemerum recurvifolium and Orthotrichum philibertii will be no longer considered as threatened taxa in the new list of the ECCB which is in the course of completion (http://www.bio.ntnu.no/ECCB). They are nonenetheless remarkable and threatened taxa in France.

Abietinella abietina (Hedw.) M.Fleisch. var. abietina

In a nitrified hem at the margin of a ruderal elm wood. Only one record.

Tab. 1. Red listed bryophytes taxa from the Gorges de l'Ardèche.

\begin{tabular}{|c|c|c|c|}
\hline Taxon & $\begin{array}{c}\text { Red Data Book of } \\
\text { European } \\
\text { bryophytes } \\
\text { (Schumacker \& } \\
\text { Martiny 1995) }\end{array}$ & $\begin{array}{c}\text { Garilleti \& } \\
\text { al. 2002 }\end{array}$ & $\begin{array}{c}\text { Red data } \\
\text { book of } \\
\text { France } \\
\text { (Depériers- } \\
\text { Robbe 2000) }\end{array}$ \\
\hline Bryum gemmiferum & Near threatened & & + \\
\hline Ephemerum recurvifolium & Rare & & + \\
\hline Orthotrichum philibertii & Vulnerable & + & + \\
\hline Orthotrichum sprucei & Rare & + & + \\
\hline
\end{tabular}




\section{Acaulon triquetrum (Spruce) Müll.Hal.}

In small quantities in the gaps of a Brachypodium retusum hem. This pioneer species is very sensitive to competition and benefits from soil disturbance originating from natural erosion, fauna movements or tourist trampling. Only one record.

\section{Alleniella besseri (Lobarz.) S. Olsson, Enroth \& D. Quandt}

North facing cliffs in woodlands. In France, a dealpine species typical of supraMediterranean Quercus humilis woodlands or poorly illuminated caves (Hébrard 1986; Hébrard \& al. 1982). Most records in the Mediterranean refer to poorly developed morphs. Two records.

\section{Alleniella complanata (Hedw.) S.Olsson, Enroth \& D. Quandt}

Previously mentioned by Wattez \& De Foucault (2002). Either on trunk or on rock. On Quercus ilex, Q. humilis, Buxus sempervirens, Populus nigra, Fraxinus excelsior, Acer monspessulanum. In humid habitats forming hanging mass of plagiotropic axes. One hundred and forty three records.

\section{Aloina aloides (Koch ex Schultz) Kindb.}

Previously mentioned by Vadam in Pierrot \& al. (1991). Found in many distinct habitats. Natural or semi-natural ones are mostly small earthy pockets at the base of calcareous cliffs and outcrops, garrigue with Thymus vulgaris and Brachypodium retusum hem. Artificial sites are evidently favoured. These include vineyards and banks along paths and roads. It is not rare in Quercus ilex woods provided there are denudated banks. Ten records

\section{Amblystegium serpens (Hedw.) Schimp.}

Only observed on bark. On one occasion near the base of a Quercus humilis, in a $Q$. ilex wood, and also in a softwood Populus nigra alluvial forest. Two records.

\section{Anomodon viticulosus (Hedw.) Hook. \& Taylor}

Saxicolous and corticolous on almost every tree species, mostly at the base of the trunk. Often in Quercus humilis and Q. ilex woods and in alluvial softwood forest. Abundant and occasionally bearing sporophytes in deep canyons. Fifty-seven records.

\section{Barbula bolleana (Müll.Hal.) Broth.}

In very small quantity on dripping rocks in the main river bed. This species shows small incrustations of tufa at its base. Owing to the local scarcity of this species it was not possible to assess its ecological requirements in details but in Argens valley (Var), Hugonnot (2011) showed that Barbula bolleana was closely mixed with Cinclidotetum danubici Empain 1973 in slightly more slow-moving ambient. Barbula bolleana is a rare species nationally. It is of local occurrence in south-eastern France (Hébrard 1970), but is considered as relatively frequent near Marseille (Bouches-du-Rhône, Squivet de Carondelet 1961). It is very rare in Pyrénées-Orientales (unpublished data). The Ardèche population, though very localized, is a significant northwards extension. It was 
not observed in nearby Chassezac valley in spite of considerable time devoted to its research in similarly potential habitats (Hugonnot 2010). The functioning of the Chassezac river is strongly impaired by hydroelectric power stations (Celle \& Hugonnot 2012) and this is the most likely explanation for the absence of this species (Celle \& Hugonnot 2012). It is not known further north, in Burgundy or in Jura but its presence remains probable. Only one record.

\section{Barbula convoluta Hedw.}

Soil in vineyards and Thymus vulgaris garrigue. Two records.

\section{Barbula unguiculata Hedw.}

Previously mentioned by Wattez \& De Foucault (2002). A most ecologically plastic species colonizing artificial habitats (vineyards, ornamental plantations in villages, along paths and roads), and banks in Quercus ilex woods, alluvial softwood forest, on muddy deposits, Thymus vulgaris garrigue, Aphyllantes monspeliensis grassland, and tufa communities. Twenty records.

\section{Brachythecium rivulare Schimp.}

On calcareous rocks in the main river channel. Three records.

\section{Brachythecium rutabulum (Hedw.) Schimp. var. rutabulum}

Mostly in woodlands (Quercus ilex or Q. humilis woods), on soil. Also in the main river channel and on certain occasion not easy to determine against $B$. rivulare. More rarely in Buxus sempervirens thickets or grasslands. Fifteen records.

\section{Bryum argenteum Hedw.}

Always in small quantities, in artificial habitats (vineyards, road banks) and on alluvial calcareous pavements and grasslands. Eight records.

\section{Bryum canariense Brid.}

In Quercus ilex woods, on humus-rich soil over calcareous pavements. It is a rare species in France (Augier 1966) although it is probably under-recorded as being member of a notoriously difficult genus. It is mostly Mediterranean (Squivet de Carondelet 1961) with isolated localities in western France (Pierrot 1982a; Hugonnot \& Jarri 2011). Two records.

\section{Bryum dichotomum Hedw.}

Abundant in vineyards, grasslands, garrigue, along paths. Seven records.

\section{Bryum gemmiferum R.Wilczek \& Demaret}

On fine alluvial sands and dripping flat alluvial pavements. It is European Red listed. Three records.

\section{Bryum gemmilucens R.Wilczek \& Demaret}

In a vineyard. One record. 


\section{Bryum gemmiparum De Not.}

On rocks in the main river channel. Tufa deposits are also favoured. Six records.

\section{Bryum radiculosum Brid.}

On small flat surfaces at the base of cliffs and active or dry tufa. Occasionally in Brachypodium retusum hem, or Thymus vulgaris garrigue. Nineteen records.

\section{Bryum ruderale Crundw. \& Nyholm}

On sand deposits or active tufa. Three records.

\section{Calliergonella cuspidata (Hedw.) Loeske}

On alluvial wet sand deposits and on active tufa. Nine records.

\section{Campyliadelphus chrysophyllus (Brid.) R.S.Chopra}

On active tufa. 3 records.

\section{Campylidium calcareum (Crundw. \& Nyholm) Ochyra}

At the base of a Quercus humilis trunk. One record.

\section{Cephaloziella baumgartneri Schiffn.}

At the base of cliffs, in small vertical depressions where a film of tufa may accumulate. Five records.

\section{Cephaloziella stellulifera (Taylor ex Spruce) Schiffn.}

On soil in Quercus ilex schrub or Thymus vulgaris garrigue. Two records.

\section{Cheilothela chloropus (Brid.) Broth.}

In Bromus erectus grasslands, in small clearings. It is a scarce species in France (Augier 1966; Husnot 1892-94). It is recorded in the Mediterranean part of France (Squivet de Carondelet 1961), Brittany (Gaume 1956; Werner 1994), and Centre-Ouest (Pierrot 1982a; Pierrot \& al. 1983). This species is very sensitive to competition and has most probably suffered a marked decline with abandonment of pastoral activities (unpublished observations). Four records.

\section{Cinclidotus danubicus Schiffn. \& Baumgartner}

Previously mentioned by Vadam in Pierrot \& al. (1991). On splashed calcareous rocks in the main river channel, in great quantities. Physiognomically important species, giving a black tinge to colonized rocks. Character species of a strongly rheophilic and speciespoor association, the Cinclidotetum danubici. This association is of particular abundance in the Gorges de l'Ardèche, whereas it is of exceptional occurrence in the otherwise comparable Chassezac valley. The putative disappearance of Cinclidotetum danubici in the Chassezac water course is linked to the regime disturbance attributable to 3 successive hydro-electric dams (Celle \& Hugonnot 2012). Nowadays in western Europe, a species mostly linked to very disturbed watercourses. Thirty one records. 


\section{Cinclidotus fontinaloides (Hedw.) P.Beauv.}

Previously mentioned by Wattez \& De Foucault (2002). On calcareous rocks and on bark of softwood (Populus alba) or hardwood (Fraxinus angustifolia) trees. Also on invasive Acer negundo trunks. Tufts of this species may accumulate significant amounts of alluvial silt and endure prolonged period of desiccation relative to $C$. danubicus. More scarcely on travertine. Ninety records.

\section{Cinclidotus riparius (Host ex Brid.) Arn.}

Occupy a somewhat intermediate level between the rheophilic aquatic $C$. danubicus and desiccation-tolerant $C$. fontinaloides. On calcareous rocks in the main river channel. Sixteen records.

\section{Cirriphyllum crassinervium (Taylor) Loeske \& M.Fleisch.}

On alluvial calcareous rocks (in softwood forests) or in humid forest habitats in canyons at the base of trunks (Quercus humilis or Q. ilex) or cliffs. Twenty two records.

\section{Cololejeunea rossettiana (C.Massal.) Schiffn.}

In Quercus ilex or more exceptionnaly in Q. humilis woods, mostly on calcareous rocks, in confined ambients. Also observed growing as epiphylic on Thamnobryum alopecurum. Thirthy three records.

\section{Conocephalum conicum (L.) Dumort.}

On active tufa. One record.

\section{Cratoneuron filicinum (Hedw.) Spruce}

On active tufa, in small temporary rivulets, under calcareous pavements. Thirteen records.

Crossidium squamiferum (Viv.) Jur. var. squamiferum and var. pottioideum (De Not.) Mönk. Previously mentioned without a subsp. by Vadam in Pierrot \& al. (1991). On very hot and dry cacareous rocks, submitted to protracted sunlight. An ecological diferentiation between the two varieties is not apparent. Eight records.

\section{Cryphaea heteromalla (Hedw.) D.Mohr}

Previously mentioned by Wattez \& De Foucault (2002). On trunk of Quercus ilex in humid woodlands, in Faxinus angustifolia-Ulmus minor or Populus nigra alluvial forests. Forty nine records.

\section{Ctenidium molluscum (Hedw.) Mitt.}

On almost every types of calcareous rocks, dry or wet, exposed to sunlight or well protected from direct radiation. All observations seem to refer to the type variety but within variety molluscum, the plants still show a certain amount of polymorphism. Fifty records.

\section{Dialytrichia saxicola (Lamy) M.J.Cano}

In alluvial soft and hardwood forests, at the base of trunks (Populus nigra, Fraxinus angus- 
tifolia, F. excelsior, Ulmus minor, Quercus ilex), on rocks. It is on certain occasion found growing on trunk, in very small quantities, in mesic woodlands (Quercus ilex forests). Also on tufa. Morphological intermediates occur between D. fragilifolia and $D$. mucronata somewhat weakening their statuts as two distinct species (Bates \& al. 2007). Sporophytes are not rare in spite of the statement of Lara (2006) that they are of exceptional occurrence in the Iberian Peninsula. Twenty six records.

\section{Dialytrichia mucronata (Brid.) Broth.}

Previously mentioned by Wattez \& De Foucault (2002). Same ecology as D. saxicola. An habitat segregation is not apparent against $D$. fragilifolia. Seventy three records.

\section{Dichodontium pellucidum (Hedw.) Schimp.}

On north facing and dripping rocks, in small quantity. One record.

\section{Dicranella howei Renauld \& Cardot}

Mostly on fine alluvial silt deposited over calcareous pavements and on eroded banks of the main river channel, wooded or not. Also in ruderal habitat, along paths and in vineyards. Thirteen records.

\section{Dicranum scoparium Hedw.}

On humus deposited over calcareous rocks in a Quercus ilex woodland and in an abandoned vineyard. Two records.

\section{Dicranum tauricum Sapjegin}

On a rotten tree of an indeterminate species lying on calcareous pavements, in the main river channel. A species not generally associated with alluvial habitats but mostly recorded in zonal mountain acidic woodlands. One record.

\section{Didymodon acutus (Brid.) K.Saito}

In a large variety of contrasting habitats. In Bromus erectus grasslands, in Thymus vulgaris garrigue, in hem, in vineyards, in woodlands. Twenty four records.

\section{Didymodon fallax (Hedw.) R.H.Zander}

In Bromus erectus grasslands, in Thymus vulgaris garrigues and in vineyards. Five records.

\section{Didymodon insulanus (De Not.) M.O.Hill}

Calcareous pavements subject to submergence, active or dry tufa. Also on trunks in softwood woodlands. Twelve records.

\section{Didymodon luridus Hornsch.}

Calcareous pavements, in the riverbed of small temporary rivulets. Rarely on trunks or on tufa. Also on eroded banks along communication axes. Occurring most frequently as dense colonies of minute stems. Eleven records. 


\section{Didymodon nicholsonii Culm.}

Exclusively on fine alluvial deposits over calcareous pavements in the main river channel. A species mentioned relatively recently in France (Stern 1989) which later proved to be of widespread occurrence (Skrzypczak 2006; Hugonnot 2007, 2010; Hugonnot \& Celle 2013). Didymodon nicholsonii appears as a typical inhabitant of artificial (Greven 1990; Hill \& al. 1992) or natural (Ahrens 1995; Nebel \& Philippi 2000) habitats in alluvial situations. It is much more abundant in Ardèche (14 records) than in Chassezac (one record) valley (Hugonnot 2012) a fact perhaps attributable to the flow regulation of the later. Fourteen records.

\section{Didymodon sinuosus (Mitt.) Delogne}

On eroded banks in a Quercus ilex woodland and on calcareous rocks in the main river channel. Two records.

\section{Didymodon tophaceus (Brid.) Lisa}

On active or dry tufa, often in mass of open turfs, then constituting true "dydimodontolith". Nine records.

\section{Didymodon vinealis (Brid.) R.H.Zander}

In almost the same habitats as $D$. insulanus but in slightly drier situations. The differentiation of $D$. insulanus and $D$. vinealis is not always straightforward despite the distinguishing characters given in the taxonomic revision of Jiménez (2006). Difficulties in determining specimens have ever been mentioned in Nebel \& Philippi (2000). Four records.

\section{Ditrichum flexicaule (Schwägr.) Hampe}

On the banks of a temporary river. One record.

\section{Ditrichum gracile (Mitt.) Kuntze}

On small cracks and horizontal surfaces on calcareous cliffs and also on alluvial deposits on calcareous pavements. Twelve records.

\section{Encalypta streptocarpa Hedw.}

On calcareous rocks, in cracks. Also on travertine. Seven records.

\section{Encalypta vulgaris Hedw.}

On earth accumulated in the cracks of calcareous rocks. Five records.

\section{Entosthodon fascicularis (Hedw.) Müll.Hal.}

In vineyards. Two records.

\section{Entosthodon pulchellus (H.Philib.) Brugués}

In a Thymus vulgaris garrigue and on rocks in a Quercus ilex woodland. It is one of the more widespread species of the genus in France so that it should no more be considered a rare Entosthodon as Philibert (1884) suggested. Two records. 


\section{Ephemerum recurvifolium (Dicks.) Boulay}

In Brachypodium retusum hem and on wet calcareous pavements. It is a rare species nationally, known in the Mediterranean and the western regions of France. Recent mentions are scarce so that the species is suspected to have suffered a marked decline but it should be kept in mind that Ephemerum colonies, or even more isolated individuals individuals, are difficult to spot. Ephemerum recurvifolium is a pioneer species very sensitive to competition. Two records.

\section{Eucladium verticillatum (With.) Bruch \& Schimp.}

Dripping tufa or dry travertine, often in mass of dense turfs at the base of cliffs. Often in caves and recesses together with Adiantum capillis-veneris. Forty eight records.

\section{Exsertotheca crispa (Hedw.) S.Olsson, Enroth \& D.Quandt}

In quantities on trunk of Quercus ilex, Q. humilis, Buxus sempervirens, Acer monspessulanum in Quercus ilex woodlands. On rock, cliffs and sinkholes. Ninety nine records.

\section{Eurhynchium striatum (Hedw.) Schimp.}

In a calcareous block scree, in a Quercus ilex wood. One record.

\section{Fabronia pusilla Raddi}

Mostly in Quercus ilex but also in Q. humilis woodlands. On the trunk of Quercus sp. or Juniperus oxycedrus. Never locally observed growing on rock. Forty records.

Fissidens crassipes Wilson ex Bruch \& Schimp. subsp. crassipes and subsp. warnstorfii (M.Fleisch.) Brugg.-Nann.

On rock periodically immersed in the main river channel, often in great quantities. Occasionally also on active tufa. Variety warnstorfii appears to be much more widespread than variety crassipes. The distinction between the two is impossible when reproductive structures are not present (Bruggeman-Nannenga 1982). Twenty one records.

\section{Fissidens dubius P.Beauv.}

In many different types of habitats of contrasting ecology. Mostly on rocks in rather dry but most often poorly illuminated situations. Quercus ilex woodlands. Also on tufa, travertine, at the base of trunks, rocks subjected to inundation. Twenty nine records.

\section{Fissidens fontanus (Bach.Pyl.) Steud.}

Rocks or roots deeply immersed in calm sectors of Ardèche river, often on the concave sides of the river. The species thrives in poorly illuminated sites and is often difficult to spot. The recent progression of the species in European watercourses has been attributed to deteriorated trophic conditions (Arts 1982; Ahrens in Nebel \& Philippi 2000). This species is most abundant in Chassezac river whereas it is of local occurrence in Ardèche which could be a sign of global pollution of the Chassezac tributary. Character species of the Octodiceratetum juliani v. Krus. ex v. Hübschm. 1953 (Neumayr 1978). Six records.

\section{Fissidens gracilifolius Brugg.-Nann. \& Nyholm}

In small colonies at the base of wet cliffs or on tufa. Five records. 


\section{Fissidens taxifolius Hedw.}

Mostly on soil in Quercus ilex woodlands, but also on rocks, on tufa or on alluvial sands.

Occasionally at the base of Quercus sp. trunk. Thirty three records.

Fissidens viridulus (Sw. ex anon.) Wahlenb. var. viridulus and var. incurvus (Starke ex Röhl.) Waldh.

Previously mentioned without a subsp. by Wattez \& De Foucault (2002). In forests, on soil, and in Brachypodium retusum hem. Rarely in alluvial forested stands, at the base of trunks or on soil. The two varieties are not always easy to tell apart and transitional forms occur (Hill \& al. 2006). Seventeen records.

\section{Fontinalis antipyretica Hedw.}

On immersed rocks or on alluvial sand deposits in the main river channel. Two records.

\section{Fontinalis hypnoides C.Hartm. var. duriaei (Schimp.) Kindb.}

Previously mentioned by Dismier 1928. On immersed rocks. Also on dripping pavements or active tufa. Sixteen records.

Fossombronia caespitiformis De Not. ex Rabenh. subsp. caespitiformis

Compacted alluvial sans and muddy deposits on calcareous pavements. Six records.

\section{Frullania dilatata (L.) Dumort.}

Previously mentioned by Wattez \& De Foucault (2002). Almost always corticolous (all tree species) but more scarcely on rock. Eighty four records.

\section{Funaria hygrometrica Hedw.}

Frequent in vineyards. Also on alluvial muddy deposits or on banks in Quercus ilex wood. Nine records.

\section{Grimmia dissimulata E.Maier}

On calcareous rocks, either exposed or well protected from direct sunlight radiation. Twenty seven records.

\section{Grimmia orbicularis Bruch ex Wilson}

On exposed calcareous rocks. Twenty one records.

\section{Grimmia pulvinata (Hedw.) Sm.}

On rocks of all lithologic nature. Rarely corticolous, on Quercus ilex, Pistacia terebinthus, Populus nigra. Thirty three records.

Grimmia tergestina Tomm. ex Bruch \& Schimp.

Only on the hottest and driest calcareous cliffs. Often accompanying but not closely admixed to Asplenium petrarchae. Twelve records. 


\section{Gymnostomum calcareum Nees \& Hornsch.}

Previously mentioned by Wattez \& De Foucault (2002). On travertine and on active tufa. Thirty three records.

\section{Gymnostomum viridulum Brid.}

Previously mentioned by Vadam in Pierrot \& al. (1991). Alluvial muddy deposits and eroded banks of the main river channel. More rarely on travertine and on Thymus vulgaris garrigue. Nine records.

\section{Habrodon perpusillus (De Not.) Lindb.}

At the middle part of trunks of Quercus ilex. More scarcely on Quercus humilis, Populus nigra, Fraxinus angustifolius, Juniperus oxycedrus. Forty seven records.

\section{Homalia lusitanica Schimp.}

In dripping caves and recesses under calcareous pavements in the main river channel. Most records refer to feebly petrifying sites with very low level of irradiance. Homalia lusitanica is a remarkable West-Mediterranean endemic (He 1997) which reaches its northern distribution limit in the Gorges of Ardèche. It is very scarce in Chassezac (Hugonnot et al. 2012) whereas relatively abundant and widespread along Ardèche course, a fact probably attributable to the artificialisation of Chassezac, to which this species is most sensitive. This is a scarce species in France, recorded in Alpes-Maritimes, Var, Gard, Hérault and Pyrénées-Orientales (Squivet de Carondelet 1961; unpublished data). A species often associated with deep gorges, ravines and caves. Eighteen records.

\section{Homalia trichomanoides (Hedw.) Brid.}

On the bark of Populus nigra in softwood alluvial forest. One record.

\section{Homalothecium aureum (Spruce) H.Rob.}

On calcareous pavements in a young Quercus ilex stand. Two records.

\section{Homalothecium lutescens (Hedw.) H.Rob. var. lutescens}

On calcareous pavements in forests, in garrigue and grasslands and in hem. Mostly on rocks and soil but on occasion on trunk. One of the most abundant species locally. Forty nine records.

\section{Homalothecium sericeum (Hedw.) Schimp.}

Previously mentioned by Wattez \& De Foucault (2002). On trunk in all types of forest habitats and on rocks. Twenty six records.

\section{Hygroamblystegium tenax (Hedw.) Jenn.}

On active tufa or immersed rocks in the main river channel. Two records.

\section{Hygrohypnum luridum (Hedw.) Jenn.}

Dripping calcareous pavements and rocks submitted to temporary immersion. Three records. 


\section{Hymenostylium recurvirostrum (Hedw.) Dixon}

On active tufa. One record.

Hypnum cupressiforme Hedw. var. cupressiforme, var. filiforme Brid. and var. lacunosum Brid.

On trunks and rocks in every types of habitats. The variety cupressiforme is very polymorphic. Hundred and fifty six records.

\section{var. filiforme Brid.}

At the base of a Quercus ilex in a $Q$. ilex woodland. One record.

var. lacunosum Brid.

Thymus vulgaris garrigue, Bromus erectus grasslands and Buxus sempervirens thicket. Six records.

\section{Imbribryum alpinum (Huds. ex With.) N.Pedersen}

In small quantities on alluvial sand deposits and on petrifying springs. The identity of some collects remains dubious due to the large polymorphism of this species and the potential occurrence of other relatives, a fact which was previously underlined in Hugonnot (2012). Four records.

Isothecium alopecuroides (Lam. ex Dubois) Isov.

Quercus ilex and Q. humilis woodlands at the base of Quercus sp. or Acer campestre trunks. Four records.

\section{Jungermannia atrovirens Dumort.}

Dripping cliff. Three records.

\section{Kindbergia praelonga (Hedw.) Ochyra}

On soil in a hardwood alluvial forest. One record.

\section{Lejeunea cavifolia (Ehrh.) Lindb.}

Mostly in Quercus ilex but also in $Q$. humilis woodlands. On trunks, eroded banks, rocks, cliffs, rotten wood. Eighty two records.

\section{Leptodictyum riparium (Hedw.) Warnst.}

On wet alluvial deposits among roots and in vineyards. Eight records.

\section{Leptodon smithii (Hedw.) F.Weber \& D.Mohr}

Previously mentioned by Wattez \& De Foucault (2002). Most often on trunk in Quercus ilex woodlands. On Quercus humilis, Fraxinus angustifolia, Ulmus minor, Populus nigra. Often in great quantities. Also on rocks and at the base of cliffs, in block screes. A deviant morph is not rarely recorded which is mostly constituted by an agglomeration of uncoiling filiform axes bearing reduced leaves (flagelliform branchlets). It is frequently linked by intermediate forms to typical $L$. smithii. This morph was previously encountered and named variety filescens by Renauld (Jelenc 1953) but is considered a nom. nud. in Wijk \& al. (1964). Such form lacks paraphyllia and shares many similari- 
ties with the recently described Leptodon corsicus Enroth, Sotiaux, D.Quandt \& Vanderpoorten (Sotiaux \& al. 2009). A taxonomic reappraisal is needed to gain a better understanding of the variability of Leptodon smithii and to reassess the value of L. corsicus. Hundred and twenty records.

\section{Leskea polycarpa Hedw.}

Previously mentioned by Wattez \& De Foucault (2002). In soft and hardwood alluvial forests, on trunks of Populus nigra, Acer negundo, Fraxinus angustifolia, F. excelsior, Ulmus minor. Also on rocks in the main river channel. Thirty three records.

\section{Leucodon sciuroides (Hedw.) Schwägr.}

Previously mentioned by Wattez \& De Foucault (2002). On trunk of Quercus ilex, Q. humilis, Juniperus oxycedrus, J. sabina, In softwood alluvial forest, on Populus nigra trunk. In vineyards on vine. Two varieties were previously recognized in the Mediterranean but they are no longer individualized (Ros \& al. 2013). The two varieties are not always clear-cut. Variety morensis (Schwägr.) De Not. is of widespread occurence in the Mediterranean. Twenty nine records.

\section{Lophocolea bidentata (L.) Dumort.}

Humicolous on banks in Quercus ilex woods. Three records.

\section{Lophocolea minor Nees}

Eroded banks in Quercus ilex woods and at the base of an old Quercus ilex trunk. Three records.

\section{Lophozia bantriensis (Hook.) Steph.}

Dripping north-facing cliff in the main river channel. One record.

\section{Lophozia turbinata (Raddi) Steph.}

On active tufa and alluvial sandy deposits in the main river channel. Seven records.

\section{Lunularia cruciata (L.) Lindb.}

Alluvial muddy deposits in the main river channel. Often in caves and recesses under calcareous pavements. On active tufa. Forty five records.

\section{Mannia californica (Gottsche ex Underw.) L.C.Wheeler}

On compacted and incrusted soil irrigated by a dripping overlying cliff. Together with Gymnostomum calcareum, Lunularia cruciata and Riccia cavernosa,. Recently mentioned in France, which was a new record for Europe (Hugonnot \& Schill 2006), this species turned out to be present in Alpes-Maritimes (Offerhaus pers. comm. and unpublished data) and Gard. Mannia californica is part of a rich assemblage of limestone species constituting hepaticological crusts (together with Cyanophyceae, liverworts and mosses). One record. 


\section{Marchantia paleacea Bertol.}

On active tufa together with Palustriella commutata in the main river channel. A scarce species in France, recorded only in the Mediterranean (Alpes-Maritimes, Var, PyrénéesOrientales) and south-west (Pyrénées-Atlantiques). Generally found in the vicinity of large tufa systems, in eroded and feebly petrifying micro-sites. One record.

\section{Marchantia polymorpha L. subsp. polymorpha}

No other subspecies could be spotted in the gorges de l'Ardèche. Small pond dominated by Eleocharis palustris in the main river channel. One record.

\section{Metzgeria furcata (L.) Dumort.}

Previously mentioned by Wattez \& De Foucault (2002). Mostly on trunk of Quercus ilex in Quercus ilex wood. Appearing abundantly on Buxus sempervirens. Also on Quercus humilis, Acer monspessulanum, Ulmus minor. Sixty three records.

\section{Microbryum curvicollum (Hedw.) R.H.Zander}

In small gaps in Thymus vulgaris garrigue, grasslands and Brachypodium retusum hem. In vineyard. A species very sensitive to competition. Four records.

\section{Microbryum davallianum (Sm.) R.H.Zander}

Aphyllantes monspeliensis grassland. One record.

\section{Microbryum starckeanum (Hedw.) R.H.Zander}

In small gaps in Thymus vulgaris garrigue, grasslands and Brachypodium retusum hem. An ecological distinction between the Microbryum is not clearly apparent locally. Four records.

\section{Microeurhynchium pumilum (Wislon) Ignatov \& Vanderp.}

On denudated mud accumulations in Quercus ilex woodlands. Seven records.

\section{Mnium marginatum (Dicks.) P.Beauv.}

On alluvial deposits on rock in the main river channel. Two records.

\section{Nogopterium gracile (Hedw.) Crosby \& W.R. Buck}

On trunk of Quercus ilex and Q. humilis in Quercus ilex woodlands. Also on rock. Thirteen records.

\section{Orthotrichum acuminatum H.Philib.}

On Quercus ilex and. Q. humilis trunks in Quercus ilex woodlands. Rarely on Buxus sempervirens, Ulmus minor. Rare in alluvial forest, on Fraxinus excelsior trunk. Forty five records.

\section{Orthotrichum affine Schrad. ex Brid.}

On Quercus ilex, Q. humilis, Populus nigra, Fraxinus angustifolia, F. excelsior, Ulmus minor, Buxus sempervirens, Pistacia terebinthus, trunks in every type of wooded habitats. Exceptionally on vine in vineyard. Forty three records. 


\section{Orthotrichum anomalum Hedw.}

On exposed calcareous rocks. On occasion on rocks submitted to irregular submergence. Rarely on trunk (Quercus ilex, Pistacia terebinthus, Populus nigra). Thirty four records.

Orthotrichum cupulatum Hoffm. ex Brid. var. cupulatum and var. riparium Huebener The variety riparium was previously mentioned by Wattez \& De Foucault (2002). On rock in the main river channel, often abundant. Often along temporary rivulets. The tufts tend to accumulate significant amounts of alluvial dust. Also on trunk (Fraxinus angustifolia, F. excelsior) in hardwood alluvial forest. The distinction between the two varieties is not always straightforward and the characters advocated as diagnostic in Lara \& al. (2009) are not always easy to use. No ecological segregation is apparent between the two. Thirty free records.

\section{Orthotrichum diaphanum Schrad. ex Brid.}

On trunk of Quercus ilex, Q. humilis, Fraxinus angustifolia, F. excelsior, Populus nigra, Pistacia terebinthus, Juniperus oxycedrus, Ulmus minor, Morus sp. in all types of wooded habitats. Also on isolated trees. Abundant on several occasion in alluvial habitats. Fifty two records.

\section{Orthotrichum lyellii Hook. \& Taylor}

Previously mentioned by Wattez \& De Foucault (2002). On trunk of Quercus ilex, Q. humilis, Buxus sempervirens, Juniperus oxycedrus mostly in young stands of Quercus ilex. Thirty four records.

\section{Orthotrichum philibertii Venturi}

On trunk of Quercus ilex, Juniperus oxycedrus, Pistacia terebinthus in young stands of Quercus ilex. A Mediterranean species mostly recorded in southeastern France which is known in Provence (Boulay 1884; Engler 1960; Hébrard 1990), Alpes-Maritimes, Alpes-de-Haute-Provence and Hautes-Alpes (Boudier \& Pierrot 1992). The species is also mentioned in western France by Pierrot \& al. (1987). It is European Red listed. It is always associated with Mediterranean woodlands or isolated trees. Four records.

\section{Orthotrichum pumilum Sw. ex anon.}

On trunk of Quercus ilex. Two records.

\section{Orthotrichum schimperi Hammar}

On trunk of Quercus ilex, Pistacia terebinthus, Ulmus minor, Juniperus oxycedrus either in forest or on isolated trees. The taxonomic status of Orthotrichum pumilum and $O$. schimperi has been debated. The distinction between the two is not always easy in spite of the key of Lara \& al. (2009). Eleven records.

\section{Orthotrichum sprucei Mont.}

On trunk of Fraxinus angustifolia, F. excelsior, Ulmus minor, Populus nigra, Quercus humilis, Platanus sp., Morus sp., Salix purpurea in alluvial soft or hardwood stands on pebble banks. This species is the character taxon of a highly specialized association, 
observed in the gorges de l'Ardèche, the Orthotrichetum sprucei which is in the course of formal description. This remarkable community is strongly linked to pioneer softwood stands in dynamic hydrosystems. The riparian forest community is characterized by a strong connectivity to the functioning of the river and the combination of four character species: Orthotrichum sprucei, O. diaphanum, Dialytrichia mucronata and Cinclidotus fontinaloides. The morphology of the main river channel, the flows of water and coarse sediments deposition are of prime importance in the maintenance of the association. Alluvial dynamics exert selective pressure on this temporary hygrophilicxerophilic association. It is a very rare association of South-Eastern France. Garilleti \& al. (2009) gave arguments towards including this species into the category of Arctotertiary relict. In France, it is recorded in Saône-et-Loire, Deux-Sèvres, Aveyron (Pierrot 1982b) and Picardie (Hauguel 2007). Thirty one records.

\section{Orthotrichum striatum Hedw.}

Previously mentioned by Wattez \& De Foucault (2002). On Quercus ilex, Q. humilis and Juniperus oxycedrus trunk in Q. ilex forests. Also on Populus nigra and Ulmus minor in alluvial forests. Thirteen records.

\section{Orthotrichum tenellum Bruch ex Brid.}

On trunk of Quercus ilex, Q. humilis, Juniperus oxycedrus, Pistacia terebinthus in Quercus ilex woodlands. Also on isolated trees. Exceptionally on vine. Forty eight records.

\section{Oxyrrhynchium hians (Hedw.) Loeske}

On soil in Quercus ilex or Q. humilis woods. In grasslands. On the banks of a temporary rivulet. On active tufa. In vineyard. Seventeen records.

\section{Palustriella commutata (Hedw.) Ochyra}

On active tufa, often abundant. Sixteen records.

\section{Pellia endiviifolia (Dicks.) Dumort.}

Active tufa and dry travertine. Also on banks of rivulets. Thirteen records.

\section{Philonotis calcarea (Bruch \& Schimp.) Schimp.}

On the banks of the main river channel. Also on active tufa. Often as tufts of very diminutive stems. The identity of such plants is made possible through measurement of the nerve width (more than $100 \mu \mathrm{m}$ wide), which exceed that of $P$. fontana and a very peculiar tissue transparency. Nine records.

\section{Plagiochila porelloides (Torrey ex Nees) Lindenb.}

In Quercus humilis wood, on north facing and humus-rich blocks. Three records.

\section{Plagiomnium rostratum (Schrad.) T.J.Kop.}

Under calcareous pavements in the main river channel. In small quantity. Two records. 


\section{Plagiomnium undulatum (Hedw.) T.J.Kop.}

On alluvial deposits in soft and hardwood forests. On soil in moist Quercus humilis wood. Also on active tufa or travertine. Twenty one records.

\section{Plasteurhynchium meridionale (Schimp.) M.Fleisch.}

On dry and humus-rich rocks in Quercus ilex wood. Two records.

\section{Plasteurhynchium striatulum (Spruce) M.Fleisch.}

Mostly on rocks and cliffs in dense Quercus ilex wood. Also on trunk (Quercus ilex, $Q$. humilis). Rarely on rotten wood. As colonies of very depauperate individuals in caves. Ninety six records.

\section{Pohlia melanodon (Brid.) A.J.Shaw}

On active tufa or dry travertine. On muddy deposits in alluvial forests. Twelve records.

\section{Porella arboris-vitae (With.) Grolle}

On rock or trunk in dense Quercus ilex or Q. humilis woodlands. Twenty one records.

\section{Porella obtusata (Taylor) Trevis.}

On rock or trunk in dense and moist Quercus ilex or Q. humilis woodlands. Sixteen records.

\section{Porella platyphylla (L.) Pfeiff.}

Previously mentioned by Wattez \& De Foucault (2002). On trunk of Quercus ilex, Q. humilis, Populus nigra in Quercus ilex woodlands or alluvial softwood forest. On rock, cliff and screes. Seventy eight records.

\section{Preissia quadrata (Scop.) Nees}

On active tufa, on travertine and on alluvial and compacted alluvial deposits. Seven records.

\section{Pseudocrossidium hornschuchianum (Schultz) R.H.Zander}

Bromus erectus grassland, Thymus vulgaris garrigue, alluvial grasslands, ruderal hem, vineyard, in small compacted clearings. Fourteen records.

\section{Pseudocrossidium revolutum (Brid.) R.H.Zander}

Observed on active tufa, a very uncommon substrate for this species. One record.

\section{Pseudoscleropodium purum (Hedw.) M.Fleisch. ex Broth.}

Bromus erectus grassland, Buxus sempervirens thicket, Quercus ilex woodland, on soil. Fourteen records.

\section{Pterygoneurum ovatum (Hedw.) Dixon}

Compacted soil in a Thymus vulgaris garrigue. One record. 


\section{Ptychostomum capillare (Hedw.) D.T.Holyoak \& N.Pedersen}

In mesic woodlands and alluvial forests. On soil, trunks and over fine alluvial deposits.

Eight records.

\section{Ptychostomum donianum (Grev.) D.T.Holyoak \& N.Pedersen}

Almost exclusively found in caves, cavities or recesses where fine alluvial deposits can accumulate. Such habitats are very dark and show a tendency to incrustation as it has already been mentioned in Païolive site (Hugonnot 2010). Nine records.

\section{Ptychostomum pallens (Sw.) J.R. Spence}

On rocks in the main river channel. The determination of this taxon is often made difficult due to the great malleability of the plant. Under certain ecological circumstances (inundation), Bryum pseudotriquetrum can produce morphs which are morphologically most similar to $B$. pallens. Three records.

\section{Ptychostomum pseudotriquetrum (Hedw.) J.R.Spence \& H.P.Ramsay}

On dripping rocks in the main river channel or on active tufa and on alluvial sands. Eight records.

\section{Ptychostomum rubens (Mitt.) D.T.Holyoak \& N.Pedersen}

In a hardwood Fraxinus angustifolia alluvial forest, over muddy deposits at the base of the trunk. One record.

\section{Ptychostomum torquescens (Bruch \& Schimp.) Ros \& Mazimpaka}

In thermophilous grasslands. Two records.

\section{Pylaisia polyantha (Hedw.) Schimp.}

Trunk of Populus nigra in a softwood alluvial forest. One record.

\section{Racomitrium canescens (Hedw.) Brid.}

Festuca lemanii alluvial sandy grassland. One record.

\section{Radula complanata (L.) Dumort.}

On trunk of Quercus ilex, Q. humilis, Buxus sempervirens, Acer monspessulanum, Juniperus oxycedrus, Ulmus minor in Quercus ilex woodland. On rock and at the base of cliffs. Hundred and sixteen records.

\section{Radula lindenbergiana Gottsche ex C.Hartm.}

On trunk of Quercus ilex in a moist Quercus ilex woodland. The determination relies strictly on fertile material. The narrowly spiciform androecia were observed and were made of more than 10 bract pairs. The collect was closely admixed to Radula complanata what complicated considerably the detection of $R$. lindenbergiana and is somehow perplexing as to the validity of the taxon. Perhaps a subsp. rank is more appropriated owing to the apparent sexual plasticity of the $R$. complanata and $R$. lindenbergiana complex (Damsholt 2002). One record. 


\section{Reboulia hemisphaerica (L.) Raddi}

Soil accumulated in the cracks of calcareous pavements. Also on travertine. Fifteen records.

\section{Rhynchostegiella curviseta (Brid.) Limpr.}

Dripping rocks and tufa in the main river channel. Eight records.

\section{Rhynchostegiella tenella (Dicks.) Limpr. var. tenella}

On small calcareous blocks and in Quercus ilex woodlands and in screes. Occasionnaly on trunk of Quercus ilex in moist woodland. In caves. Also on tufa or travertine. Fifty four records.

\section{Rhynchostegium confertum (Dicks.) Schimp.}

On rock in moist Quercus ilex woodland. A the base of Quercus ilex trunk. Also rarely on soil or rotten wood. Fifty seven records.

\section{Rhynchostegium megapolitanum (Blandow ex F.Weber \& D.Mohr) Schimp.}

On soil in open Quercus ilex woodland. In vineyard. Three records.

\section{Rhynchostegium riparioides (Hedw.) Cardot}

In the riverbed of a temporary rivulet. On active tufa. Four records.

\section{Riccia beyrichiana Hampe ex Lehm.}

Alluvial acid sandy deposits in the main river channel. Also recorded in the same type of habitat in Païolive together with Erica arborea and Cistus salviifolius (Hugonnot 2010). A species which is much more widespread and abundant in nearby Cévennes, where it is a major component of bryophyte grouping from margin of small depressions and wet heaths. One record.

\section{Riccia bifurca Hoffm.}

Small flat surfaces at the base of dripping cliffs, on compacted soil. Three records.

\section{Riccia cavernosa Hoffm. emend. Raddi}

Small flat surfaces at the base of dripping cliffs, on compacted soil. Vanden Berghen (1963) previously mentioned from North Causses this species growing in the same original habitat ("balmes suintantes"). Not recorded in Païolive site, although Riccia species are much more abundant than in Gorges of Ardèche. One record.

\section{Riccia sorocarpa Bisch.}

In Bromus erectus grassland, in Thymus vulgaris garrigue, in hem. In the vicinity of active tufa and travertine. Also in anthropogenic habitats (vineyards, compacted paths). Seventeen records.

\section{Riccia trabutiana Steph.}

Xerothermophilous, south-facing and very well protected from wind action Brachypodium retusum hem, in small soil clearing. In very small quantity. A very scarce species in 
France, being only recorded from Alpes-Maritimes (Jovet-Ast \& Debon 1960; Offerhaus pers. comm.) and Gard (Sulmont pers. comm.). It is mostly associated with calcareous grasslands. The record from Var should be checked. It reaches its known north limit in Ardèche. Two records.

\section{Riccia warnstorfii Limpr. ex Warnst.}

On accumulated soil pockets in the calcareous pavements in the main river channel. Small flat surfaces at the base of dripping cliffs, on compacted soil. Three records.

\section{Scapania aspera M.Bernet \& Bernet}

On humus-rich rock, in moist Quercus ilex woodland. In small quantities and often depauperated. Four records.

\section{Schistidium apocarpum (Hedw.) Bruch \& Schimp.}

On periodically immersed rock in the main river channel. One record.

\section{Schistidium crassipilum H.H.Blom}

On all types of rock, either very dry or periodically immersed. In small quantity. Five records.

\section{Schistidium elegantulum H.H.Blom subsp. elegantulum}

On calcareous pavements, in Quercus ilex woodland. Occasionnaly on Quercus ilex trunk, in small tuft. Thirty records.

\section{Schistidium helveticum (Schkuhr) Deguchi}

At the base of xerothermophilous cliffs. Five records.

\section{Scleropodium touretii (Brid.) L.F.Koch}

On bank in a Quercus ilex woodland. One record.

\section{Scorpiurium circinatum (Bruch) M.Fleisch. \& Loeske}

On rock, trunk and soil in Quercus ilex, Q. humilis woodland. Also in grasslands, either on small block or directly on soil. Occasional on active tufa, travertine, or alluvial forest. As very depauperate individuals in caves. Ninety three records.

\section{Scorpiurium deflexifolium (Solms) M.Fleisch. \& Loeske}

Previously mentioned by Dismier (1928). On periodically immersed rocks in the main river channel. Occasionally on trunk (Populus nigra, Fraxinus excelsior) in alluvial forest. Rare on active tufa. Sixty three records.

\section{Scorpiurium sendtneri (Schimp.) M.Fleisch.}

Under an overhang in a Quercus humilis woodland. A very scarce species nationally, being only confidently recorded in nearby Païolive site (Hugonnot 2010) and in Ardèche basaltic Coiron (unpublished records). One record. 


\section{Seligeria acutifolia Lindb.}

In dense and mostly sterile colonies on withered limestone cliffs, in small recesses protected from direct sunlight. On one occasion on small blocks in a scree in $Q$. ilex woodland. 13 records.

\section{Southbya nigrella (De Not.) Henriq.}

Active tufa and travertine, dripping or moist rocks. Also on soil in Thymus vulgaris garrigue. Eleven records.

\section{Southbya tophacea (Spruce) Spruce}

Active tufa and travertine, dripping or moist rocks. The habitat affinities of the two species of Southbya are not as clear cut as the litterature seems to incidate. Under calcareous pavements in the main river channel. Twenty two records.

\section{Syntrichia calcicola J.J.Amann}

Festuca lemanii alluvial grassland. Six records.

\section{Syntrichia laevipila Brid.}

Only on trunk of a wide variety of trees (Quercus ilex, Q. humilis, Populus nigra, Pistacia terebinthus, Fraxinus angustifolia, F. excelsior, Ulmus minor, Morus sp.) in woodlands or on isolated trees. Sixty records.

\section{Syntrichia latifolia (Bruch ex Hartm.) Huebener}

Alluvial soft and hardwood forests on trunk of Fraxinus angustifolia, F. excelsior, Ulmus minor, Acer negundo, Morus sp., Populus nigra, at a short distance from the permanent riverbed. Twenty three records.

Syntrichia montana Nees var. montana and var. calva (Durieu \& Sagot ex Bruch \& Schimp.) J.J.Amann

On rock in small colonies, in well illuminated sites. In forest only in young and open stands. Thirty eight records. Only one record of the variety calva.

\section{Syntrichia papillosa (Wilson) Jur.}

On trunk of Quercus ilex, Q. humilis, Fraxinus angustifolia, Ulmus minor on well illuminated forest or on isolated trees. Twenty four records.

\section{Syntrichia ruralis (Hedw.) F.Weber \& D.Mohr var. ruralis and var. ruraliformis} (Besch.) Delogne

Only variety ruraliformis previously mentioned by Petit (2002). Bromus erectus grassland. Aphyllanthes monspeliensis grassland. Alluvial sandy grassland. Ruderal hem. Five records of the variety ruralis. One record of variety ruraliformis.

\section{Thamnobryum alopecurum (Hedw.) Gangulee}

Moist to dripping rocks in obscure Quercus ilex or Q. humilis woodlands. Block on main river channel, submitted to submergence. Alnus glutinosa alluvial forest. Occasionally on active tufa or travertine. Nineteen records. 


\section{Timmiella anomala (Bruch \& Schimp.) Limpr.}

Alluvial sand desposited under calcareous pavements, in caves and recesses. Twelve records.

\section{Tortella humilis (Hedw.) Jenn.}

On trunk of Quercus ilex in young Quercus ilex stands. Three records.

\section{Tortella inclinata (R.Hedw.) Limpr. var. inclinata}

Festuca lemanii alluvial sandy grassland. Aphyllanthes monspeliensis grassland. In denudated and compacted sectors. Six records.

\section{Tortella inflexa (Bruch) Broth.}

Small withered limestone block in a Quercus ilex woodland. A rare species in France (Hébrard 1990) where mostly recorded in western regions (Pierrot 1958; Boudier 1986) and the Mediterranean in Vaucluse, Var, Bouches-du-Rhône, Alpes Maritimes (Hébrard 1990; Hugonnot 2011). One record.

\section{Tortella nitida (Lindb.) Broth.}

On calcareous blocks and pavements in fully insolated sites or semi-shaded in Quercus ilex woodland. A very variable species which encompass morphs approaching T. tortuosa in general appearance but readily differentiated by the progressive transition of the basal cells towards chlorophyll cells. Rarely on Quercus ilex trunk. Fifty records.

\section{Tortella squarrosa (Brid.) Limpr.}

Bromus erectus grasslands, Brachypodium retusum hem, Thymus vulgaris garrigue, alluvial grasslands, Aphyllanthes monspeliensis grasslands, ruiniform rocks in Quercus ilex or $Q$. humilis woodlands, block screes, vineyard. Sporophytes of exceptional occurrence. Sixty one records.

\section{Tortella tortuosa (Hedw.) Limpr. var. tortuosa and var. fragilifolia (Jur.) Limpr.}

Same substrates than Tortella nitida but much more shade-loving and often in Quercus humilis woodland. Twenty records. One record of the variety fragilifolia which is doubtfully distinct (Eckel 2010).

\section{Tortula acaulon (With.) R.H.Zander var. acaulon}

In vineyards and ornamental flowerbed. Rarely in grasslands. Five records.

\section{Tortula atrovirens (Sm.) Lindb.}

Along a road in small soil pockets on rock. One record.

\section{Tortula inermis (Brid.) Mont.}

On rock in an open Quercus ilex stand. Along a road in small soil pockets on rock. Three records.

\section{Tortula lindbergii Broth.}

In vineyard and in ruderal hem. Six records. 


\section{Tortula caucasica Broth.}

In vineyard and along path. Four records.

\section{Tortula muralis Hedw.}

On rock fairly well illuminated, or in open Quercus ilex woodland and in block scree. Eleven records.

\section{Tortula protobryoides R.H.Zander}

In vineyards and Thymus vulgaris garrigue. Three records.

\section{Trichostomum brachydontium Bruch}

On exposed rock or in young Quercus ilex stands. In Bromus erectus grassland. Alluvial sandy deposit in the main river channel. Along paths. Seventeen records.

\section{Trichostomum crispulum Bruch}

On rock and at the base of cliff. Travertine. In Thymus vulgaris garrique. Banks of small temporary rivulets. Also in grassland and in hem. Sixty five records.

\section{Ulota crispa (Hedw.) Brid.}

On trunk of Quercus humilis in Quercus humilis woodland. In small quantity among numerous members of the genus Orthotrichum. One record.

Weissia brachycarpa (Nees \& Hornsch.) Jur.

Aphyllanthes monspeliensis grassland. Cracks of calcareous pavements. Rarely on trunk of Quercus humilis. Six records.

Weissia condensa (Voit) Lindb. var. condensa

Previously mentioned by Wattez \& De Foucault (2002). Thymus vulgaris garrigue. Brachypodium retusum hem. Ten records.

Weissia controversa Hedw. var. controversa and var. crispata (Nees \& Hornsch.) Nyholm

On soil in Thymus vulgaris garrigue, Aphyllanthes monspeliensis grassland and Quercus ilex woodland. Seven records. One record of the variety crispata.

Weissia levieri (Limpr.) Kindb.

Thymus vulgaris garrigue and Bromus erectus grassland. A species sensitive to competition occurring in small gaps of the vegetation. Three records.

\section{Weissia longifolia Mitt.}

On soil on bank of a temporary rivulet. One record.

\section{Zygodon rupestris Schimp. ex Lorentz}

Previously mentioned by Wattez \& De Foucault (2002). On trunk of old Quercus ilex or Q. humilis in dense Quercus ilex woodland. Ninety one records. 


\section{Discussion}

In a recent synthesis Païolive site was pointed out as one of the most remarkable spots of south-eastern France. It includes a total of 304 taxa (Hugonnot 2010; Hugonnot \& al. 2013) so that it appears much more diversified than the Gorges de l'Ardèche from a strict bryofloristic point of view. Almost 100 taxa which were recorded in Païolive site remain currently unrecorded in the Gorges de l'Ardèche, a fact attributable to the absence or the poor spatial extension of many habitats. Among the most notable are the Quercus humilis woodlands on ruiniform limestone that are so typical of Païolive site and are mostly absent in the Gorges de l'Ardèche. Several communities of wet grasslands are also lacking in the Gorges de l'Ardèche. Yet this site should by no means be considered as poor in bryophytes. Compared with other recently investigated local bryoflora (Tab. 2) it clearly stands out as one of the richest site and should then be considered a local hot-spot.

Several genera are especially well represented locally. The 8 species of the genus Didymodon exemplifies a soil dwelling group fairly well diversified in the Gorges as a consequence of a wide range of microhabitats. Didymodon acutus or D. fallax are warm and dry loving species mostly found in open grasslands whereas at the other extreme, $D$. nicholsonii is restricted to alluvial rocks. Didymodon tophaceus is typically growing on active tufa. The 12 species of the genus Orthotrichum illustrate the variety of ecological combinations favourable to the mostly bark-dwelling members of this genus. Orthotrichum acuminatum, O. lyellii, O. tenellum are mostly found in dry Quercus ilex woodlands. Orthotrichum sprucei and $O$. diaphanum are on the contrary dependant on regular submergence in alluvial softwood communities. Bryum, Fissidens or Riccia are also 3 genera of particular interest because of a high diversification locally.

Tab. 2. Bryofloristic richness of investigated sites in southeastern France.

\begin{tabular}{|c|c|c|c|}
\hline Site & Department & $\begin{array}{l}\text { Species } \\
\text { number }\end{array}$ & Reference \\
\hline $\begin{array}{l}\text { Gorges de } \\
\text { l'Ardèche }\end{array}$ & Ardèche/Gard & 216 & Present study \\
\hline Lubéron & Bouches-du-Rhône & 135 & Hébrard 1990, 2005 \\
\hline $\begin{array}{c}\text { Provence } \\
\text { occidentale }\end{array}$ & Var & 209 & Hébrard \& al. 1982 \\
\hline Larzac & Aveyron/Lozère & 207 & Pierrot \& al. 1983 \\
\hline Sainte-Victoire & Var & 91 & Hébrard 1986 \\
\hline Sainte-Baume & Bouches-du-Rhône/Var & 187 & Hébrard 2003 \\
\hline $\begin{array}{c}\text { North of } \\
\text { department }\end{array}$ & Bouches-du-Rhône/Var & 91 & Hébrard 1986 \\
\hline $\begin{array}{c}\text { Hautes vallées } \\
\text { du Verdon et } \\
\text { du Var }\end{array}$ & $\begin{array}{c}\text { Alpes-de-Haute- } \\
\text { Provence/Alpes- } \\
\text { Maritimes }\end{array}$ & 259 & Hébrard 2005 \\
\hline
\end{tabular}


The combined occurrence there of so many interesting species consolidates the hot-spot status of the site. Most species are clearly linked to xerothermophilous grasslands and associated habitats. Acaulon triquetrum, Bryum canariense, Cheilothela chloropus, Ephemerum recurvifolium, Homalothecium aureum, Mannia californica, Riccia cavernosa and $R$. trabutiana are the best examples. Amphibious and aquatic species are Aleniella besseri, Barbula bolleana, Cinclidotus danubicus, Didymodon nicholsonii, Fissidens fontanus and Marchantia paleacea. Rock dwelling species are Grimmia tergestina, Homalia lusitanica, Scorpiurium sendtneri, Tortella inflexa and Timmiella anomala. Orthotrichum philibertii, Orthotrichum sprucei and Radula lindenbergiana are bark linked species. Numerous species are largely dependant upon the natural functioning of the Ardèche river, with an intense alluvial activity and remodelling of river banks. The alluvial functioning of Chassezac river appears largely deteriorated as reflected in the scantiness of flooddemanding taxa (Celle \& Hugonnot 2013; Hugonnot 2010).

In spite of this, a lot of remarkable taxa known from Païolive are notably absent in the Gorges de l'Ardèche. Antitrichia californica and Zygodon forsteri deserve special mention since they are both clearly inhabitants of ancient woodlands that are lacking in Gorges de l'Ardèche. In the Gorges de l'Ardèche, most of accessible habitats are young ones, originating from forest recolonization of ancient pastoral areas whereas the long forested continuity of Païolive is a remarkable attribute of large areas of ruiniform woodlands (Hugonnot 2010).

Yet water quality problems should not be ignored as phytocoenotic signals point to a trophic deterioration of Ardèche. Batrachion fluitantis communities have increased significantly in the last few years and they express eutrophication in the watercourse. Although no historical data are available this issue should be considered as a potential explanation for the rarity of the more oligotrophic and demanding species (Barbula bolleana, Marchantia palleacea) and the occurence of Leptodictyum riparium or Hygroamblystegium varium in the waste water disposal systems of many campsites along the Ardèche course.

The near absence of a rotten wood-dwelling bryoflora deserves to be underlined. The assemblage of species are as poor in Païolive, where significant areas of ancient woodlands with large amounts of coarse woody debris are known, than in Gorges de l'Ardèche, where rotten wood is largelly lacking. It seems to be a characteristic of the Mediterranean rotten wood where only a few ubiquitous species (mostly Hypnum cupressiforme var. cupressiforme) are able to invade dead trunks. Water relation may explain the near absence of liverworts (Lophocolea heterophylla excepted) in the Mediterrean rotten wood bryfolora since most of the specialized taxa are very demanding ones (Stokland \& al. 2012).

The conservation of the bryophyte communities is theoretically very simple and shall be based upon the principle of minimum intervention. The richness of the alluvial systems is strictly dependant upon a natural functioning of the hydrosystem which would be fatally destroyed in case of hydro-electrical amenagements. The water qual- 
ity could be improved by a better calibration of the waste water disposal systems of campsites. The woodlands ecosystems will greatly benefit from maturing without silvicultural practices. The grasslands are perhaps the only ecosystem to require active management such as pastoralism.

\section{Aknowledgements}

Denis Doublet and Olivier Peyronel (Réserve Naturelle Nationale des Gorges de l'Ardèche) helped on many occasion in the field and provided financial support to the present study. Guillaume Choisnet (Conservatoire Botanique National du Massif Central) provided insight for the vegetation description. Thierry Vergne (Conservatoire Botanique National du Massif Central) made the maps illustrating this article. Emeric Sulmont (Parc National des Cévennes) and Benoît Offerhaus (Conservatoire Botanique National de Porquerolles) provided unpublished records.

\section{References}

Ahrens, M. 1995: Das laubmoose Barbula nicholsonii Culm. am nördilchen Oberrhein und am Neckar (Südwestdeutschland). - Carolinea 53: 229-241.

Arts, T. 1982: De verspreiding von Octodiceras fontanum (La Pyl.) Lindb. in de Kempische Kanalen von Belgie en Nederland. - Dumortiera 24: 23-24.

Astrade, L., Jacob-Rousseau, N. \& Allignol, F. 2011: Les successions d'interactions entre climat, sociétés et paysages dans un contexte de changements: les moyennes montagnes du sud-est de la France à la sortie du Petit Age Glaciaire. in: Lambiel, C., Reynard, E., \& Scapozza, C. (Éds). La géomorphologie alpine: entre patrimoine et contrainte. - Act. Coll. Soc. Suisse Géomorph. 36: $60-78$.

Augier, J. 1966: Flore des Bryophytes. - Paris.

Bates, J.W., Matcham, H.W. \& Lara, F. 2007: Dialytrichia fragilifolia (Bryopsida: Pottiaceae) in Berkshire and Caernarvonshire, new to Britain. - J. Bryol. 29: 228-234.

Boudier, P. 1986: Quelques données nouvelles sur la Bryoflore de la Basse-Conie et de la Vallée du Loir entre Bonneval et Cloyes-sur-le-Loir (Eure-et-Loir). Seligeria donniana (Sm.) C. Muller, Seligeria paucifolia (Dicks.) Carruth, Gymnostomum calcareum Nees et Horns., Tortella inflexa (Bruch) Broth., Fissidens viridulus Wahl. Muscinées nouvelles pour l'Eure-et-Loir. - Bull. Amis Mus. Chartres Nat. Eure-et-Loir 5: 34-37.

— \& Pierrot, R.B. 1992: Contribution à la bryoflore des Hautes-Alpes et des alpes de HauteProvence. - Bull. Soc. Bot. Centre-Ouest, N.S. 23: 319-334.

Boulay, A. 1884: Muscinées de la France. Deuxième partie, Hépatiques. F. Savy, Libraire-Editeur, 216 p. - Paris.

Bravard, J.-P. 1993: Quelques caractères de la morphodynamique fluviale des Gorges de l'Ardèche. In: Géomorphologie et Aménagement de la Montagne, Mélanges en hommage à P. Gabert, CNRS : 23-42. - Caen.

- 2008: L'eau et les paysages du fond des Gorges. - In: De la Dent de Rez aux Gorges de l'Ardèche. - Lagorce.

Bruggeman-Nannenga, M.A. 1982: The section Pachylomidium (genus Fissidens) III. The F. crassipes-subcomplex (F. bryoides-complex), F. sublineaefolius (Pot. Varde) Brugg.-Nann. and $F$. fluitans (Pot. Varde) Brugg.-Nann. - Kon. Ned. Akad. Wetensch. C. 85(1): 59-104.

Celle, J. \& Hugonnot, V. 2012: Les communautés bryophytiques du lit mineur des Gorges de l'Ardèche comme témoins de sa richesse écosystémique. - Ecol. Medit. 38: 29-41.

Damsholt, K. 2002: Illustrated Flora of Nordic Liverworts and Hornworts. - Lund. 
Debat, L. 1886: Catalogue des mousses du Bassin du Rhône. - Ann. Soc. Bot. Lyon 13: 147-235.

Depériers-Robbe, S. 2000: Etude préalable à l'établissement du Livre rouge des Bryophytes menacées de France métropolitaine. - Caen.

Dismier, G. 1921: Florule bryologique de St-Péray (Ardèche). - Rev. Bryol. 48: 72.

- 1922: Une Mousse nouvelle pour la France dans la Drôme: Orthotrichum Schawii Wils., et présence aux environs de Valence des Camptothecium aureum Bry. Eurr. et Epipterygium Tozeri (Grev.) Lindb. - Bull. Soc. Bot. France 69(3-4): 221-225.

- 1928: Les Muscinées du Vivarais. - Rev. Bryol. 1(1): 13-25.

Eckel, P. 2010: Tortella bambergeri in North America and an evaluation of its taxonomy. - Bull. Buffalo Soc. Nat. Sci. 39: 1-10.

Engler, A. 1960: Die natürlichen Pflanzenfamilien. 11 band. Musci. 2 Hälfte. - Berlin.

Garilleti, R., Lara, F., Albertos, B. \& Mazimpaka, V. 2002: Datos preliminares para una Lista Roja de las especies europeas del género Orthotrichum Hedw. (Musci). - Conserv. Veg. 7: 3-5.

-, Medina, R., Mazimpaka, V. \& Lara F. 2009: Bryological notes. Orthotrichum hispanicum in the Turkish Caucasus and Kashmir. - J. Bryol. 31: 46-47.

Gaume, R. 1956: Catalogue des Muscinées de Bretagne d'après les documents inédits du Dr F. Camus. - Rev. Bryol. Lichénol. 25(1-2): 1-117.

Greven, H.C. 1990: Didymodon nicholsonii Culm. (Pottiaceae) een nieuwe sort voor de Nederlandse mosflora. - Lindbergia 16: 69-72.

Hauguel, J.-C. 2007: Observations récentes de Blasia pusilla L., Leiocolea bantriensis (Hook.) Joerg., Orthotrichum sprucei Mont., Plasteurhynchium striatulum (Spruce) Schimp., Racomitrium heterostichum (Hedw.) Brid. et Tomenthypnum nitens (Hedw.) Loeske en Picardie. - Bull. Soc. Linn. Nord-Picardie 25: 119-123.

He, S. 1997: A revision of Homalia (Musci: Neckeraceae). - J. Hattori Bot. Lab. 81: 1-52.

Hébrard, J.-P. 1970: Formations muscinales rupicoles de Provence cristalline. - Ann. Fac. Sci. Marseille 44: 99-119.

Hébrard, J.-P. 1986: Aperçu sur la bryoflore des terrains calcaires, aux confins septentrionaux des départements des Bouches-du-Rhône et du var. - Bull. Soc. Linn. Provence 38: 127-138.

— 1990: Contribution à l'étude bryologique du Petit Lubéron (Vaucluse) I. Les contreforts orientaux (région de Bonnieux). - Cryptog. Bryol. Lichénol. 11(3): 319-328.

- 2003: Contribution à l'étude de la bryoflore du massif de la Sainte-Baume (Bouches-du-Rhône et Var). - Cryptog. Bryol. 24(2): 127-146.

- 2005: Contribution à l'étude de la bryoflore des hautes vallées du Verdon (Alpes-de-HauteProvence) et du Var (Alpes-Maritimes). - Cryptog. Bryol. 26(2): 183-207.

- 2006: Contribution à l'étude bryologique du Petit Lubéron (Vaucluse) II. La Crête, le versant sud et l'extrémité occidentale du masif. - Cryptog. Bryol. 27: 253-264.

—, Lecointe, A., Pierrot, R.B., \& Schumacker, R. 1982: Bryophytes observées pendant la huitième session extraordinaire de la Société botanique du Centre-Ouest en Provence occidentale. Bull. Soc. Bot. Centre-Ouest, N.S. 13: 182-209.

Hill, M.O., Bell, N., Bruggeman-Nannenga, M.A., Brugués, M., Cano, M.J., Enroth, J., Flatberg, K.I., Frahm, J.-P., Gallego, M.T., Garilleti, R., Guerra, J., Hedenäs, L., Holyoak, D.T., Hyvönen, J., Ignatov, M.S., Lara, F., Mazimpaka, V., Muñoz, J. \& Söderström, L. 2006: Bryological Monograph - An annotated checklist of the mosses of Europe and Macaronesia. J. Bryol. 28: 198-267.

—, Preston, C.D. \& Smith, A.J.E. 1992: Atlas of the bryophytes of Britain and Ireland, 2. Colchester.

Hugonnot, V. 2004: Contribution à la chorologie et à l'écologie des Ricciacées du Massif Central, principalement de l'Ardèche et de la Haute-Loire. - Cryptog. Bryol. 25(1): 39-67. 
— 2007: Bryophytes nouvelles pour l'Auvergne (France), approches chorologique et écologique. J. Bot. Soc. Bot. France 39: 3-15.

- 2008: New national and regional records, 18. Scorpiurium sendtneri (Schimp.) M.Fleisch. - J. Bryol. 30: 161-166.

- 2010: Mousses et hépatiques de Païolive (Ardèche et Gard, France). - Bull. Soc. Bot. CentreOuest, N.S., numéro spécial 34: 1-293.

— 2011: Les bryophytes et les bryocénoses du site d'Entraygues (Var, France) comme outil d'évaluation d'un projet de renaturation hydrologique. - Ecol. Medit. numéro spécial 37(2): 45-56.

— \& Celle, J. (to be published): A new epiphytic paradoxical association of south-western France : the Orthotrichetum sprucei. - Limprichtia.

— \& Celle, J. 2013: Les bryophytes du corridor alluvial de la vallée du Rhône : flore, végétation et fonctionnalité. - Rev. Écol. (Terre et Vie) 67: 3-23.

— \& Jarri, B. 2011: Un haut-lieu de la bryologie du Massif armoricain : les grottes de Saulges (Mayenne) - Utilité des bryophytes dans la gestion du site. - Erica 24: 37-56.

— \& Schill, D. 2006: Mannia californica (Gottsche ex Underw.) L.C.Wheeler (Aytoniaceae, Marchantiales) in Ardèche (France), new to Europe. - Cryptog. Bryol. 27(1): 181-189.

—, Celle, J., Vergne, T. \& Sulmont, É. 2012: Compléments aux «mousses et hépatiques de Païolive ». - Bull. Soc. Bot. Centre-Ouest, N.S. 43: 679-683.

Husnot, T. 1892-1894: Muscologia Gallica. Descriptions et figures des mousses de France et des contrées voisines.- Cahan.

Jaillet, S., Martini, J., Mocochain, L. \& Delannoy, J.-J. 2008: Le cadre naturel : approche géomorphologique. - In: De la Dent de Rez aux Gorges de l'Ardèche. - Lagorce.

Jélenc, F., 1953: Muscinées de l'Afrique du Nord (Algérie, Tunisie, Maroc, Sahara). - Bull. Soc. Géogr. Arch. Oran 76: 44.

Jiménez, J.A. 2006: Taxonomic revision of the genus Didymodon Hedw. (Pottiaceae, Bryophyta) in Europe, North Africa and Southwest and Central Asia. - J. Hattori Bot. Lab. 100: 211-292.

Jovet-Ast, S. \& Debon, E. 1960: Nouveautés pour la flore bryologique française. - Rev. Bryol. Lichénol. 29: 130-131.

Julien, P.Y. 2006: River mechanics. - Cambridge.

Kerguélen, M. 1993: Index synonymique de la flore de France. - Coll. Patrimoines Nat. 8: 1-196.

Lara, F. 2006: 35. Dialytrichia (Schimp.) Limpr., - Pp. 264-269 in: Guerra J. \& Mazimapaka V. (eds.), Flora Briofítica Ibérica. - Murcia.

—, Garilleti, R., Medina, R. \& Mazimpaka, V. 2009: A new key to the genus Orthotrichum Hedw. in Europe and the Mediterranean region. - Cryptog. Bryol. 30(1): 129-142.

Mandin, J.-P. \& Descoings, B. 2008: Flore et végétation. - In: De la Dent de Rez aux Gorges de l'Ardèche. - Lagorce.

Mardigny, M. De 1860: Mémoire sur les inondations des rivières de l'Ardèche. - Ann. Ponts et Chaussées 19(3): 249-296.

Meyran, O. 1914: Catalogue des mousses du bassin du Rhône. - Ann. Soc. Bot. Lyon 39: 1-164.

Nebel, M. \& Philippi, G. 2000: Die Moose Baden-Württembergs, 1. - Stuttgart.

Neumayr, L., 1978: Verbreitung und Ökologie von Octodiceras fontanum (La Pyl.) Lindb., in Bayern. - Hoppea 37: 179-240.

Pascal, M., Lafarge, D., Chedhomme, \& Glintzboeckel, C. 1989: Notice explicative de la feuille de BOURG-SAINT-ANDÉOL, Carte géologique de la France à 1/50000. - Paris.

Petit, D., 2002: Vallée de l'Ibie et les Gorges de l'Ardèche. Journée du 19 avril 2001. - Bull. Soc. Bot. N. Fr. 55: 11-13.

Philibert, H. 1880: Le véritable Thuidium delicatulum Hedw. et Lindb., trouvé à Vals. - Rev. Bryol. 7: 99 .

— 1881: Orthotrichum acuminatum species nova. - Rev. Bryol. 8: 28-31. 
- 1884a: Funaria pulchella sp. nov. - Rev. Bryol. 11: 41.

- 1894b: Philonotis nouvelles ou critiques. - Rev. Bryol. 21: 2.

Pierrot, R.-B. 1958: Tortella inflexa (Bruch) Broth. et Leptobarbula barica (de Not.) Schp. en Charente-Maritime. - Féd. Française Soc. Sci. Nat. 14: 81-83.

- 1982a: Les bryophytes du Centre-Ouest : Classification, détermination, répartition. - Bull. Soc. Bot. Centre-Ouest, N.S., 5: 1-123.

- 1982b: Orthotrichum sprucei Mont. En France. Comparaison avec O. rivulare Turn. - Bull. Soc. Bot. Centre-Ouest, N.S., 13: 229-233.

- 1987: L'année bryologique 1986. - Bull. Soc. Bot. Centre-Ouest, N.S., 18: 117-120.

- 1991: Contribution à l'inventaire de la bryoflore française (année 1990). - Bull. Soc. Bot. CentreOuest, N.S., 22: 503-506.

—, Boudier, P. \& Houmeau, J.M. 1983: Liste des bryophytes observées pendant la 9ème session extraordinaire de la SBCO : "Grands causses cévenols et Lévezou-Aigoual". - Bull. Soc. Bot. Centre-Ouest, N.S., 14: 141-147.

Ros, R.M., Mazimpaka, V., Abou-Salama, U., Aleffi, M., Blockeel, T.L., Brugués, M., Cano, M.J., Cros, R.M., Dia, M.G., Dirkse, G.M., El Saadawi, W., Erdağ, A., Ganeva, A., GonzálezMancebo, J.M., Herrnstadt, I., Khalil, K., Kürschner, H., Lanfranco, E., Losada-Lima, A., Refai, M.S., Rodríguez-Nuñez, S., Sabovjlević, M., Sérgio, C., Shabbara, H., Sim-Sim, M., Söderström, L. 2007: Hepatics and Anthocerotes of the Mediterranean, an annotated checklist. - Cryptog. Bryol. 28(4): 351-437.

—, 一, 一, 一, 一, 一, Cros, R.M., Dia, M.G., Dirkse, G.M., Draper, I., El-Saadawi, W., Erdağ, A., Ganeva, A., Gabriel, R., González-Mancebo, J.M., Granger, C., Herrnstadt, I., Hugonnot, V., Khalil, K., Kürschner, H., Losada-Lima, A., Luís, L., Mifsud, S., Privitera, M., Puglisi, M., Sabovljević, M., Sérgio, C., Shabbara, H.M., Sim-Sim, M., Sotiaux, A., Tacchi, R., Vanderpoorten, A., Werner, O. 2013: Mosses of the Mediterranean, an annotated checklist. Cryptog. Bryol. 34: 99-283.

Sapaly, J. 2000: Bryophytes du département de l'Ardèche. Manuscrit non publié, non paginé. Aurillac.

Schumacker, R. \& Martiny, P., 1995: Threatened bryophytes in Europe including Macaronesia. - Pp. 29-193 in: European Committee for Conservation of Bryophytes (ed.), Red Data Book of European Bryophytes. - Trondheim.

Skrzypczak, R. 2006: Didymodon nicholsonii Culm. dans le département de la Loire. - Bull. Soc. Bot. Centre-Ouest, N.S., 37: 387-392.

Sotiaux, A., Enroth, J., Olsson, S., Quandt, D. \& Vanderpoorten A. 2009: When morphology and molecules tell us different stories: a case-in-point with Leptodon corsicus, a new and unique endemic moss species from Corsica. - J. Bryol. 31: 186-196.

Squivet de Carondelet, J. 1961: Mousses de Montpellier et contributions diverses à la bryologie du Sud-Est de la France (plaines et basses montagnes). - Naturalia Monspel., Série bot., 13: $73-185$.

Stern, R.C. 1989: Didymodon nicholsonii Culm. new to France. - Cryptog. Bryol Lichénol. 10(2): 171-172.

Stokland, J.N., Siitonen, J. \& Jonsson B.G. 2012: Biodiversity in Dead Wood. Ecology, Biodiversity and Conservation. - Cambridge.

Vanden Berghen, C. 1963: Quelques Bryophytes des Grands Causses septentrionaux (Aveyron et Lozère). - Rev. Bryol. Lichénol. 32: 56-64.

Wattez, J.-R. \& Foucault, B. De 2002: Esquisse de la végétation bryophytique de la Basse-Ardèche. - Bull. Soc. Bot. Nord France 55(3-4): 27-32. 
Werner, J. 1994: Cheilothela chloropus (Brid.) Broth. en Bretagne, et quelques autres observations de Bryophytes dans le Finistère. - Bull. Soc. Bot. Centre-Ouest, N.S., 25: 379-383.

Wijk Van der, R., Margadant, W.D. \& Florschütz, P.A. 1964: Index Muscorum, 3. - Utrecht.

Address of the author:

Vincent Hugonnot,

Conservatoire Botanique National du Massif Central, le Bourg, 43270 Chavaniac Lafayette, France E-mail: vincent.hugonnot@,cbnmc.fr 